\title{
Komunikacja międzypokoleniowa w polskiej kulturze. Wyniki badań empirycznych
}

\section{Wstęp}

Niniejsza praca jest wynikiem wstępnych badań nad komunikacją międzypokoleniową w dyskursie kulturowym. Czynnikiem, który miał wpływ na sformułowanie tematu i przeprowadzenie związanych z nim badań, jest fakt wyodrębniania się kolejnego pokolenia i jego specyficzne egzystowanie w przestrzeni publicznej. Dokładna analiza przyzwyczajeń kulturowych, społecznych i socjolingwistycznych oraz aktów komunikacji publicznej danego pokolenia jest podstawą do analizy zachowań społecznych czy lingwistycznych konkretnego społeczeństwa, ale też dyskursu publicznego. Segmentacja pokoleniowa pozwala dostrzegać i łączyć potrzeby ludzi nie tylko $\mathrm{w}$ procesie rozwoju zawodowego, lecz także pozwala dostrzec zmiany $\mathrm{w}$ dyskursie społecznym, które odzwierciedlają idee, wartości i potrzeby społeczeństwa. Poznanie habitusu ${ }^{1}$ lub języka młodych ludzi może mieć wpływ na budowanie bardziej efektywnej komunikacji społecznej kierowanej do tej grupy przez instytucje kulturalne, firmy komercyjne, polityków, media czy innych przedstawicieli dyskursu publicznego.

W tym artykule skupiono się na analizie tylko jednej płaszczyzny, jaką jest komunikacja dyskursu kulturowego, kierowana do różnych pokoleń. Badanie przeprowadzone w wersji pilotażowej miało dać odpowiedź na pytanie, czy dyskurs ten dostrzega zamiany pokoleniowe, czy dopasowuje swoje komunikaty do konkretnych grup społecznych i czy uważa, że zmiana pokoleniowa może mieć wpływ na kulturę

${ }^{1}$ P. Bourdieu, Struktury, habitus, praktyki, przeł. L. Kopciewicz, [w:] Socjologia. Lektury, red. P. Sztompka, M. Kucia, Kraków 2005. s. 503-508. 
w Polsce. Podejmowany tutaj problem autorka traktuje jako zjawisko o charakterze komunikacyjnym, społecznym, kulturowym i systemowym.

Dotychczasowe badania aktów komunikacji w dyskursie pokoleń przeważnie przebiegają jednostronnie, co oznacza, że naukowcy skupiają się zazwyczaj wyłącznie na komunikacji nadawcy (tutaj: pokolenia), nie analizując sprzężeń zwrotnych dyskursu publicznego. Nie można jednak analizować dyskursu jedynie przez pryzmat jego struktur językowych. W naukach społecznych metodę analizy dyskursu stosuje się w badaniach konstruowania wizerunku społecznego, a także przy projektowaniu tożsamości zbiorowych lub struktur dyskursu publicznego. Teun van Dijk twierdzi, że „należy patrzeć ponad dyskursem, biorąc pod uwagę jego środowiska: kognitywne, społeczne, polityczne, kulturowe i historyczne"2. W dalszych rozważaniach przedstawia go jako trójwymiarową strukturę. Pierwszy wymiar to sama czynność użycia języka, następnie zawarcie w dyskursie idei, a ostatni — społeczne interakcje. W tym wypadku nie analizowano konkretnych aktów komunikacji, a skupiono się tylko na idei oraz społecznych interakcjach dyskursu kulturowego.

\section{Przedmiot badań}

Teoria poznania, jaką jest konstruktywizm, daje punkt wyjścia do tejże pracy badawczej. Pogląd ten w dyskursie społecznym zasadniczo mówi o tym, że ludzie postrzegają rzeczywistość, która ich otacza, poprzez pryzmat swojej kultury i doświadczeń. Michael Fleischer konstatuje, że „wypowiedzi na temat rzeczywistości są produktami wewnątrzsystemowego, kognitywnego przyporządkowania znaczeń obiektom, które same w sobie znaczeń nie posiadają"3. Z kolei według Maurycego Graszewicza

koordynacja zachowań przez komunikację nie służy przekazywaniu informacji, obiektów, obrazów czy dźwięków, a jedynie naszych przechowywanych w układzie nerwowym wyobrażeń o nich. [...] Każdy organizm słyszy to, co słyszy, na podstawie indywidualnych doznań i przyporządkowań neuronalnych. Słyszenie, tak jak widzenie i poznanie, nie jest „wspólne”, lecz indywidualne. Nie wiemy, co słyszy osoba siedząca obok nas ${ }^{4}$.

Warto dodać, że konstruktywizm jest sformułowany jako teoria poznania daleko odchodząca od teorii postrzegania. Wyjaśniając tło teoretyczne dla zawartych w tej pracy badań, w dalszej części przybliżono definicje pojęć, które wykorzystano podczas projektowania i analizy badań.

2 T.A. van Dijk, Kontekstualizacja w dyskursie parlamentarnym, [w:] Krytyczna analiza dyskursu: interdyscyplinarne podejście do komunikacji społecznej, red. A. Duszak, F. Fairclough, Kraków 2008, s. 216.

${ }^{3}$ M. Fleischer, Konstrukcja rzeczywistości, Wrocław 2002, s. 13.

${ }^{4}$ M. Graszewicz, Polski system polityczny. Semantyki i struktury komunikacji politycznej, Wrocław 2011, s. 43. 
W literaturze przedmiotu komunikacja „nie jest niczym innym, jak stosującym znaki i sterowanym przez znaki mechanizmem orientacyjnym i negocjacyjnym służącym do wytworzenia i zabezpieczenia systemu społecznego" ${ }^{5}$. Dalej, za Fleischerem, uznano, iż możemy przyjąć

następujący szereg: modus, program komunikacyjny i system funkcyjny. Program komunikacyjny realizowany jest za pośrednictwem modusów w dyskursach różnej kompleksowości, produkując przez to systemy funkcyjne, które ze swej strony realizują się przez grupy społeczne, supragrupy i społeczeństwa. To wszystko w systemie społecznym ${ }^{6}$.

Podsumowując, ujmując tę kwestię najprościej, można stwierdzić, że nie ma społeczeństwa bez komunikacji. Wszystko jest komunikacją i nawet jeżeli nie komunikujemy, to komunikujemy ${ }^{7}$. Jeżeli chodzi zaś o dyskurs kulturowy, to samo pojęcie „kultura” rozumiane jest zgodnie z podejściem normatywnym. Definicję zaczerpnięto z kultury symbolicznej, zwanej również duchową, w której szczególną uwagę zwrócono na jej aspekt społeczny. Talcott Parsons uważa, że kultura to produkowane i przekazywane treści i modele, zawierające pewne idee, zbiory wartości i inne systemy symboli, które są czynnikami kształtującymi ludzkie zachowania ${ }^{8}$.

Przechodząc do kwestii pokolenia, należałoby podkreślić, że jest to szeroko omawiany termin $\mathrm{z}$ dziedziny nauk społecznych. W literaturze przedmiotu zauważa się cztery kategorie, w ramach których można zoperacjonalizować to zjawisko: zasada pokrewieństwa, kohorta, etap życia i okres historyczny. Interpretacja danej grupy społecznej skupia się na wyodrębnieniu jej cech, określa model jej zachowania i podkreśla skłonności językowe. Socjologowie przywołują konkretne wydarzenia historyczne lub technologiczne, które mogą stać się granicą międzypokoleniową ${ }^{9}$. Socjologiczna teoria pokolen ${ }^{10}$ jest głównym motywem do podjęcia analizy tematu dotyczącego konstruktu pokoleń w nauce o komunikacji i ujęciu socjolingwistycznym. Jeżeli zatem dyskurs jest pewną interakcją komunikacyjną, która mogłaby być pretekstem do przekazania lub odbioru pewnych, istotnych dla danych grup społecznych informacji, to aktorzy tego dyskursu powinni szczególną uwagę zwracać nie tylko na treść merytoryczną aktów komunikacji, lecz także na formę oraz język, które mogą przyczynić się do powstania nieporozumień między nadawcą a odbiorcą.

${ }^{5}$ M. Fleischer, Ogólna teoria komunikacji, Wrocław 2007, s. 17.

${ }^{6}$ Ibidem, s. 25-26.

7 Ibidem, s. 12.

8 A.L. Kroeber, T. Parsons, The concepts of culture and of social systems, „American Sociological Review" 1958, nr 3, s. 583.

${ }^{9}$ W. Wrzesień, Czy pokoleniowość nam się przydarzy? Kilka uwag o współczesnej polskiej młodzieży, „Nauka” 2007, nr 3, s. 131.

10 J. Garewicz, Pokolenie jako kategoria socjofilozoficzna, „Studia Socjologiczne” 1983, nr 1, s. 77. 


\section{Badania}

Odwołując się do paradygmatu nauk o komunikacji społecznej oraz nauk socjologicznych, podjęto próbę badawczą, za pomocą której chciano wykazać, iż podział społeczeństwa na pokolenia ma bezpośredni wpływ na komunikację dyskursu publicznego (zarówno tę kreowaną przez dyskurs publiczny, jak i tę, którą tworzy konkretne pokolenie).

Głównym celem przeprowadzonych badań pilotażowych było potwierdzenie problemu badawczego, który brzmiał następująco: dyskurs kulturowy dostrzega zmianę pokoleniową i kreuje komunikację w zależności od pokolenia, do którego ma być ona skierowana. Szukano odpowiedzi m.in. na pytania, czy polska kultura jest zdeterminowana przez jej uczestników? Czy rozróżnia się jej odbiorców ze względu na jakieś konkretne czynniki? Czy globalizacja, przez aspekt której bada się najmłodsze pokolenie, ma wpływ na kulturę w Polsce? Czy wydarzenia organizowane przez instytucje kultury są kierowane do konkretnych odbiorców i jakie są to wydarzenia? Oraz czym jest kultura oraz kim jest jej odbiorca w ogóle? W tym celu postawiono również pewne hipotezy. I tak np. założono, że kultura w Polsce skupia się wokół trzech aspektów: ludzi, którzy ją tworzą, grona odbiorców oraz obecnej sytuacji w kraju. Uznano także, że dyskurs kulturowy tworzy komunikację w zależności od pokolenia, do którego ma być ona skierowana, co dalej wskazuje, iż instytucje kulturalne dostrzegają zmianę pokoleniową w Polsce.

Badania przeprowadzono w maju 2016 r. Formularz był ankietą online (metoda CAWI), został rozesłany do kilkunastu instytucji kulturalnych w Polsce. W efekcie otrzymano 21 wypełnionych ankiet, które przeanalizowano metodą jakościową ${ }^{11}$.

Wyniki badania empirycznego

1. Podaj miasto i instytucję kulturalną, w której pracujesz.

\begin{tabular}{|l|c|}
\hline \multicolumn{1}{|c|}{ Miasto i instytucja kulturalna, w której pracuję } & N \\
\hline $\begin{array}{l}\text { Wrocław (w tym: Impart - 9, Europejska Stolica Kultury 2016 - 2, Ośrodek Pamięć } \\
\text { i Przyszłość, Narodowe Forum Muzyki, Instytut im. Grotowskiego, Dolnośląska Szkoła } \\
\text { Wyższa) }\end{array}$ & 16 \\
\hline Warszawa (Fundacja PEROFRM) & 2 \\
\hline Kraków (Teatr Instytucjonalny) & 1 \\
\hline Kielce (Instytut Dizajnu) & 1 \\
\hline
\end{tabular}

${ }^{11}$ E. Babbie, Podstawy badań społecznych, przeł. W. Betkiewicz, Warszawa 2008. 


\begin{tabular}{|c|c|c|}
\hline Miasto i instytucja kulturalna, w której pracuję & & $\mathrm{N}$ \\
\hline Legnica (Teatr Avatar) & & 1 \\
\hline & Suma & 21 \\
\hline
\end{tabular}

Źródło: opracowanie własne.

Respondenci to głównie osoby pracujące w instytucjach kulturalnych we Wrocławiu. Większość $\mathrm{z}$ nich w momencie wypełniania ankiety zadeklarowała, że pracuje przy Europejskiej Stolicy Kultury Wrocław 2016 lub w Biurze Festiwalowym Impart, które w 2016 r. również było jej częścią. Wśród ankietowanych osób znalazły się też osoby pracujące w fundacji, w teatrze czy w szkole wyższej. Ankieta została wypełniona także przez pracowników instytucji z Warszawy, Krakowa, Kielc czy Legnicy. Łącznie ankietę wypełniło 21 osób, co w wersji pilotażowej było wystarczającą próbą do jakościowej analizy wyników.

2. Podaj dział, w którym pracujesz.

\begin{tabular}{|c|c|}
\hline Dział, w którym pracuję & $\mathrm{N}$ \\
\hline promocja, komunikacja, marketing & 6 \\
\hline dział merytoryczny (edukacja) & 5 \\
\hline produkcja & 4 \\
\hline zarząd (koordynator projektu) & 4 \\
\hline inne: logistyka, administracja, artysta & 4 \\
\hline brak odpowiedzi & 1 \\
\hline Suma & 24 \\
\hline
\end{tabular}

Źródło: opracowanie własne.

Ankietowani to przede wszystkim osoby pracujące w dziale promocji, merytorycznym lub przy produkcji eventów, są to jednak także osoby pełniące funkcje zarządzające - instytucją, zespołem czy projektem. Dzięki temu, iż respondenci pełnią różne role $\mathrm{w}$ instytucjach kulturalnych, odpowiedzi mogły okazać się bardziej różnorodne, a sytuacje były widziane oczami osób, które mają zupełnie inne punkty styku z odbiorcami kultury. To wszystko sprawia, że obraz kultury w Polsce, który przedstawia poniższa analiza wyników, jest jeszcze bardziej wartościowy. 
3. Odpowiedz na pytanie: jaka jest współczesna kultura polska?

\begin{tabular}{|c|c|}
\hline Jaka jest współczesna kultura polska? & $\mathrm{N}$ \\
\hline różnorodna (wielowymiarowa, dużo, gęsto, w różnej jakości) & 9 \\
\hline dynamiczna (spontaniczna, chaotyczna, prężna, progresywna) & 7 \\
\hline sprecyzowana (sprekaryzowana, szyta na miarę) & 6 \\
\hline intelektualna (wymagająca, ambitna, awangardowa, innowacyjna) & 6 \\
\hline wtórna (czerpiąca z różnych gatunków) & 6 \\
\hline odważna wobec wyzwań współczesnego świata (komentująca aktualną sytuację w kraju) & 5 \\
\hline nudna (gnuśna, mało progresywna, homogeniczna) & 4 \\
\hline łatwo dostępna (niedoceniana) & 4 \\
\hline $\begin{array}{l}\text { mało zaangażowana społecznie (promowana „wśród swoich”, skumulowana w dużych } \\
\text { miastach) }\end{array}$ & 4 \\
\hline $\begin{array}{l}\text { zagrożona (w cieniu potęg kulturalnych, niedofinansowana, bez odpowiedniej } \\
\text { infrastruktury) }\end{array}$ & 4 \\
\hline ważna dla społeczeństwa (schlebia widzowi) & 3 \\
\hline projektowo pusta, w stylu MTV & 3 \\
\hline krytyczna (kontrowersyjna, buntownicza) & 3 \\
\hline kreatywna (pomysłowa, ciekawa, świeża) & 3 \\
\hline zależna (polityczna) & 2 \\
\hline spolaryzowana (zbyt błahe rzeczy vs nieznośnie „alternatywne”, paradoksalna) & 2 \\
\hline stonowana (bezpieczna) & 2 \\
\hline na światowym poziomie & 1 \\
\hline międzykulturowa i międzynarodowa (posiadająca duży kapitał ludzki) & 1 \\
\hline inne: piękna, seksowna & 2 \\
\hline
\end{tabular}

Źródło: opracowanie własne.

Pytanie to miało zweryfikować, jak respondenci rozumieją pojęcie kultury i jakie wiążą z tym słowem skojarzenia, czy kultura posiada pozytywne, czy negatywne konotacje. Okazało się, że kultura w Polsce jest bardzo różnorodna. Ankietowani odpowiadali na wiele sposobów. Czasami odnosili się do samej kultury i określali ją 
rozmaitymi przymiotnikami, jak „dynamiczna”, „chaotyczna”, „różnorodna”, „awangardowa”, „łatwo dostępna”. W innych odpowiedziach respondenci zaznaczali, że kultury nie należy oceniać przez pryzmat sytuacji politycznej w kraju:

Jeśli ograniczymy rozumienie kultury tylko do sfery działalności artystycznej (oraz do wąskiego środowiska współczesnych twórców, działających w opozycji względem polityki kulturalnej prowadzonej przez obecne władze), te cechy to: odwaga, krytyczność (zwłaszcza względem polityki historycznej), ale też wtórność wobec niektórych wzorców zachodnich.

Wskazywano na jej rozbieżność:

ważna dla społeczeństwa, odważna wobec wyzwań współczesnego świata, reprezentuje światowy poziom. Jednocześnie bywa gnuśna, nudna i projektowo pusta.

Podsumowując, należy stwierdzić, że kultura rozumiana jest przez pryzmat jakości, ludzi oraz obecnej sytuacji w państwie. Podkreślano fakt, iż jest ona ważna dla społeczeństwa, ale jednocześnie zaznaczano, że jest mało zaangażowana społecznie.

4. Odpowiedz na pytanie: gdzie pojawiają się informacje o wydarzeniach kulturalnych w Polsce?

\begin{tabular}{|r|l|}
\hline & \multicolumn{1}{|c|}{ Gdzie pojawiają się informacje o wydarzeniach kulturalnych w Polsce? } \\
\hline 1. & Internet, billboardy, radio, telewizja, przestrzeń miejska \\
\hline 2. & Internet, analogowe nośniki zewnętrzne, materiały ulotne \\
\hline 3. & TV (programy kulturalne), miejsca publiczne, słupy ogłoszeniowe \\
\hline 4. & $\begin{array}{l}\text { punkty turystyczne i kulturalne, strony www miast, instytucji kultury i organizacji non } \\
\text { profit, aplikacje }\end{array}$ \\
\hline 5. & plakaty, Facebook \\
\hline 6. & Internet, Facebook, prasa, słupy ogłoszeniowe, ulotki, bilbordy, szeroko pojęta reklama \\
\hline 7. & www, Facebook, plakaty, newslettery \\
\hline 8. & $\begin{array}{l}\text { strona www MKiDN, NCK, strony poszczególnych instytucji, we Wrocławiu } \\
\text { go.wroclaw.pl, fanpage instytucji na Facebooku }\end{array}$ \\
\hline 9. & Facebook, strony internetowe instytucji kultury \\
\hline 10. & na Facebooku poszczególnych instytucji, gazety, newslettery poszczególnych instytucji \\
\hline 11. & Internet, prasa codzienna, prasa opiniotwórcza, radio, outdoor \\
\hline 12. & Facebook, Internet, radio, gazety tematyczne, TV \\
\hline 13. & $\begin{array}{l}\text { specjalistyczne portale internetowe, media papierowe, radio, telewizja, media } \\
\text { społecznościowe, obieg towarzyski }\end{array}$ \\
\hline
\end{tabular}




\begin{tabular}{|c|l|}
\hline & \multicolumn{1}{|c|}{ Gdzie pojawiają się informacje o wydarzeniach kulturalnych w Polsce? } \\
\hline 14. & $\begin{array}{l}\text { Internet, na portalach społecznościowych, w gazetach, na portalach tematycznych, na } \\
\text { plakatach }\end{array}$ \\
\hline 15. & Facebook - eventy i fanpage, ulotki, plakaty, media konwencjonalne, głuchy telefon \\
\hline 16. & $\begin{array}{l}\text { Facebook instytucji, portale internetowe (np. taniecpolska), programy telewizyjne } \\
\text { dotyczące kultury }\end{array}$ \\
\hline 17. & Internet, ulotki, broszury, czasopisma, radio \\
\hline 18. & radio, Internet, plakaty, broszury, telewizja \\
\hline 19. & $\begin{array}{l}\text { Facebook, radio, prasa branżowa, blogi, reklamy na bilbordach, ulotki, plakaty, puby, } \\
\text { knajpy, kina, biblioteki }\end{array}$ \\
\hline 20. & media społecznościowe \\
\hline
\end{tabular}

Źródło: opracowanie własne.

Pytanie to miało zweryfikować, czy już na poziomie wyboru narzędzi do komunikacji o wydarzeniach kulturalnych twórcy kultury mogliby wykluczać $\mathrm{z}$ udziału w tych wydarzeniach pewne grupy społeczne. Na przykład, jeśli w odpowiedziach pojawiłyby się tylko media społecznościowe lub inne formy przekazu informacji drogą elektroniczną, mogłoby to oznaczać, iż ogranicza się grupę odbiorców tylko do osób młodych i w średnim wieku - tych, którzy korzystają z Internetu. W zaprezentowanej tabeli ukazano wszystkie odpowiedzi. Chciano zobrazować, że prawie każdy ankietowany wymieniał zarówno media tradycyjne, jak i media społecznościowe. Najczęściej pojawiał się Internet (strony www, Facebook i inne social media), a także telewizja, radio i prasa w ogóle. Zwrócono również uwagę na materiały promocyjne, takie jak ulotki, plakaty, i wymieniono miejsca, gdzie te materiały mogłyby być dystrybuowane (infopunkty, puby, kina czy słupy ogłoszeniowe). Tylko dwie osoby wskazały na formę marketingu szeptanego, czyli przekazywanie informacji w obiegu towarzyskim.

5. Scharakteryzuj odbiorcę, do którego adresowane są wydarzenia kulturalne w Polsce.

\begin{tabular}{|l|c|}
\hline \multicolumn{1}{|c|}{$\begin{array}{c}\text { Scharakteryzuj odbiorcę, do którego adresowane są wydarzenia kulturalne } \\
\text { w Polsce }\end{array}$} & N \\
\hline wykształcony (oczytany, umysł humanistyczny, ambitny, uczący się) & 11 \\
\hline zaangażowany (w kulturę, społecznie, w sprawy polityczno-społeczne) & 11 \\
\hline $18-50$ lat & 6 \\
\hline
\end{tabular}




\begin{tabular}{|c|c|}
\hline $\begin{array}{c}\text { Scharakteryzuj odbiorcę, do którego adresowane są wydarzenia kulturalne } \\
\text { w Polsce }\end{array}$ & $\mathrm{N}$ \\
\hline ludzie młodzi & 5 \\
\hline różnorodny & 4 \\
\hline duże miasto & 3 \\
\hline średnia pensja & 3 \\
\hline aktywny (kontaktowy) & 2 \\
\hline klasa wyższa & 2 \\
\hline twórczy (kreatywny) & 2 \\
\hline $\begin{array}{l}\text { inne: zorganizowany, świadomy, nieśmiały, pokorny, alternatywny, narcystyczny, } \\
\text { krytyczny i wrażliwy na krytykę, często obcokrajowiec }\end{array}$ & 8 \\
\hline
\end{tabular}

Źródło: opracowanie własne.

Pytanie było otwarte, miało zachęcić respondentów, aby w sposób subiektywny opisali odbiorcę kultury w Polsce. Odpowiedzi miały pokazać, na jakie aspekty zwraca się uwagę u adresatów kultury. Głównymi wymiernymi okazały się: wiek, wykształcenie, pochodzenie oraz zarobki. Według respondentów uczestnik wydarzeń kulturalnych jest dobrze wykształcony i mieści się w przedziale wiekowym 18-50 lat, raczej dużo zarabia i wykazuje zainteresowanie i zaangażowanie w działalność kulturową, społeczną czy polityczną. Nie potrzebuje informacji promocyjnej, bo o wydarzeniach wie, interesuje się nimi przed ich promocją. Charakterystyczny odbiorca jest osobą zainteresowaną różnymi dziedzinami (jak np. muzyka czy taniec), ale skupia się na jednej, dominującej dziedzinie (jak teatr). Jest gotów spędzić popołudnie/wieczór w dni robocze na wybranym wydarzeniu, okazjonalnie poświęcić weekend lub kilka-kilkanaście dni na dłuższe wydarzenie (np. festiwal). Jednorazowo wydaje kilkanaście-kilkadziesiąt złotych na bilet/produkt (np. książkę).

6. Odpowiedz na pytanie: czy globalizacja ma wpływ na realizację wydarzeń kulturalnych w Twoim mieście? Odpowiedź uzasadnij.

\begin{tabular}{|c|c|}
\hline Czy globalizacja ma wpływ na realizację wydarzeń kulturalnych w Twoim mieście? & $\mathrm{N}$ \\
\hline tak & 19 \\
\hline nie & 1 \\
\hline nie mam zdania & 1 \\
\hline
\end{tabular}

Źródło: opracowanie własne. 
Globalizacja to jedno z głównych zjawisk, przez pryzmat których analizuje się najmłodsze pokolenie (pokolenie Z). Większość respondentów uważa, że globalizacja ma wpływ na realizację wydarzeń kulturalnych, ponieważ oddziałuje na świat, w którym żyjemy, a więc również na kulturę. Swoje odpowiedzi motywują tym, że powstaje coraz więcej projektów międzynarodowych oraz coraz więcej treści przystosowanych nie tylko do lokalnego odbiorcy, lecz także do obcokrajowców. Zwrócono uwagę również na to, że coraz częściej podejmuje się tematy, które mają na celu edukację międzynarodową, a celem wielu projektów jest zwiększanie świadomości różnic międzykulturowych, większy dostęp i lepsze rozpowszechnianie informacji o wydarzeniach czy czerpanie wzorców/inspiracji z innych krajów. Dzięki globalizacji twórcy czerpią inspiracje z wydarzeń światowych i przenoszą je na rodzimą scenę i własne twory kultury. Ma pozytywne skutki, ponieważ powstają ambitne przedsięwzięcia $\mathrm{z}$ udziałem światowej klasy artystów i gromadzące widownię z różnych stron świata.

Często wymieniano takie przedsięwzięcia, jak: dotacje unijne, rezydencje artystyczne, możliwość zapraszania grup artystycznych oraz teatrów z całego świata. Zwrócono również uwagę na to, że sztuka wrocławska często porusza globalne trudności, takie jak konsumpcjonizm czy polityka. Pojawiają się programy dla expatów, sporo informacji jest $\mathrm{w}$ języku angielskim, ale niestety często kończy się na samych informacjach - można więc stwierdzić, że globalizacja ma wpływ na kulturę, ale nie tak wielki, jak mogłoby się wydawać. Ankietowani podkreślali też, że dzięki globalizacji łatwiej można dostrzec zjawisko zmian kulturowych, które rozwija się przede wszystkim dzięki łatwemu dostępowi do środków transportu oraz szybkiemu rozprzestrzenianiu się informacji.

Bardziej sceptyczne osoby uważają natomiast, że globalizacja nie ma wpływu na wydarzenia kulturalne, ponieważ każdy i tak organizuje event dla siebie, a wydarzenia często się kanibalizują. Wśród odpowiedzi pojawił się również głos, iż ma słaby wpływ; nie taki, jaki mieć powinna. Jednak tych negatywnych wypowiedzi było zdecydowanie mniej niż pozytywnych.

Podsumowując, można uznać, że pracownicy instytucji kulturalnych dostrzegają globalizację i budują swoją komunikację przez pryzmat różnych grup kulturowych, tak aby dotrzeć do jak najszerszego grona odbiorców. Może to oznaczać, iż dana informacja jest personalizowana pod kątem odbiorcy.

7. Odpowiedz na pytanie: kim są odbiorcy kultury w Polsce?

\begin{tabular}{|l|c|}
\hline \multicolumn{1}{|c|}{ Kim są odbiorcy kultury w Polsce? } & N \\
\hline są w pewnym wieku (młodzi ludzie - 10, średni wiek — 2, seniorzy, dzieci) & 14 \\
\hline wykształceni (studenci - 3) & 10 \\
\hline działacze kultury (pracownicy kreatywni, artyści) & 8 \\
\hline wąskie grono zainteresowanych (miłośnicy kultury) & 4 \\
\hline
\end{tabular}




\begin{tabular}{|l|c|}
\hline \multicolumn{1}{|c|}{ Kim są odbiorcy kultury w Polsce? } & $\mathrm{N}$ \\
\hline klasa średnia & 3 \\
\hline z miasta & 3 \\
\hline turyści & 2 \\
\hline mają pieniądze & 2 \\
\hline otwarci & 2 \\
\hline nie wiem & 1 \\
\hline inne: świadomi, bez kompleksów, różnorodni & 3 \\
\hline
\end{tabular}

Źródło: opracowanie własne.

Odbiorców najczęściej interpretowano przez pryzmat wieku, w związku z czym wyróżniono ludzi młodych, osoby w średnim wieku, seniorów i dzieci. Na szczególną uwagę zasługuje również kategoria „wykształcenie”. Podkreślano, iż mogą to być osoby zainteresowane kulturą, szukające wydarzeń w Internecie i w prasie, o wysokim statusie społecznym (materialnym lub intelektualnym), lecz także może to być grono osób wykształconych $\mathrm{z}$ dużych ośrodków, bo - jak podkreśla jeden z respondentów — „reszta społeczeństwa ma telewizję". Zwrócono też uwagę, że mogłoby to być wąskie grono osób zapalonych wydarzeniami kulturalnymi. Zarówno kobiety, jak i mężczyźni reprezentujący całe spektrum wiekowe. Charakteryzuje ich jednak poziom wykształcenia (zazwyczaj są po studiach), a w przypadku dzieci - wykształcenia rodziców.

Jak widać, nie ma jednoznacznej odpowiedzi. Łatwo jednak spostrzec, że respondenci nie wymieniali cech charakteru, a raczej skupili się na dwóch głównych czynnikach, takich jak wiek i wykształcenie, które według nich są najbardziej widoczne wśród odbiorców kultury.

8. Odpowiedz na pytanie: do kogo adresowane są wydarzenia kulturalne w Polsce?

\begin{tabular}{|l|c|}
\hline \multicolumn{1}{|c|}{ Do kogo adresowane są wydarzenia kulturalne w Polsce? } & N \\
\hline ludzie młodzi & 10 \\
\hline dla wszystkich osób: seniorzy, dzieci i ludzie młodzi / w średnim wieku & 5 \\
\hline ludzie w średnim wieku & 4 \\
\hline ludzie zaangażowani w kulturę & 2 \\
\hline
\end{tabular}

Źródło: opracowanie własne.

To pytanie w formie zamkniętej miało zwrócić uwagę respondentów wyłącznie na kategorię wiekową. Powtórzyły się odpowiedzi z poprzednich pytań, gdzie wymie- 
niano głównie osoby młode lub zwracano uwagę, iż uczestnicy wydarzeń kulturalnych są w różnym wieku. W kategorii „inni” pojawiły się natomiast dwie odpowiedzi, które ukazały, że wiek nie jest istotny, a liczy się to, czy jednostki są zaangażowane w działalność kulturalną.

9. Odpowiedz na pytanie: czy informacja kulturalna jest tworzona w zależności od odbiorcy, do którego ma dotrzeć? Jeśli tak, podaj przykład.

\begin{tabular}{|l|c|}
\hline \multicolumn{1}{|c|}{$\begin{array}{c}\text { Czy informacja kulturalna jest tworzona w zależności od odbiorcy, do którego } \\
\text { ma dotrzeć? }\end{array}$} & $\mathrm{N}$ \\
\hline tak & 15 \\
\hline raczej nie & 3 \\
\hline nie & 2 \\
\hline nie wiem & 1 \\
\hline
\end{tabular}

Źródło: opracowanie własne.

Respondenci potwierdzili jedną z głównych hipotez, iż dyskurs publiczny ukierunkowuje swoje przekazy do poszczególnych grup społecznych, jakimi są pokolenia. Podkreślano, że informacja jest tworzona w zależności od wieku odbiorcy i tak np. to, co dla młodzieży, ogłaszane jest w sposób wirtualny, na Facebooku, a do seniorów dociera się poprzez ulotki, pozytywne opinie, radio czy telewizję. Internet w dużej mierze wyklucza seniorów, do których bardziej przemawia informacja drukowana, która zazwyczaj ma prostą formę i jest zapisana większą czcionką. Informacje określają również odbiorcę za pomocą środków przekazu i języka wypowiedzi.

Warto zwrócić w tym miejscu uwagę na festiwale awangardowe, które mają bardzo specyficzny design, również określający specyficznego odbiorcę. Przykładem takich działań mogłaby być reklama promująca jesienne działania kulturalne w ramach ESK 2016: „Taki jesteś kozak? Zmierz się z kulturą!” czy: „Coś Cię bierze? Kultura dostępna bez recepty”.

To, czy komunikacja tworzona jest pod pewien target, zależy głównie od organizatora i budżetu. Uwagę zwrócono także na narrację takich komunikatów - inna będzie narracja reklam polsatowskich koncertów disco polo, a inna choćby Jazzu nad Odrą. Natomiast osoby, które uważają, iż informacja kulturalna jest jednakowa dla wszystkich grup odbiorców, argumentowały swoją odpowiedź tym, że komunikaty podawane są w sposób, który stwarza barierę uczestnictwa już przez pryzmat samego komunikatu. Informacje są redagowane zazwyczaj zbyt sucho lub zbyt naukowo, posługują się branżowym żargonem.

10. Odpowiedz na pytanie: czy realizowałeś lub brałeś udział w wydarzeniach kulturalnych organizowanych dla osób w różnym wieku? Jeśli tak, jakie były to wydarzenia? 


\begin{tabular}{|l|c|}
\hline \multicolumn{1}{|c|}{$\begin{array}{c}\text { Czy realizowałeś lub brałeś udział w wydarzeniach kulturalnych organizowanych } \\
\text { dla osób w różnym wieku? }\end{array}$} & N \\
\hline tak & 19 \\
\hline nie & 2 \\
\hline
\end{tabular}

Źródło: opracowanie własne.

Respondenci nie mieli problemu z wymienieniem wielu kierowanych do osób w różnym wieku wydarzeń, które współtworzyli lub w których uczestniczyli. Pytanie miało potwierdzić, iż ankietowani znają konkretne przykłady wydarzeń, dla których określi narzędzia, komunikację i odbiorców tej komunikacji. I tak wymieniano: potańcówki dla seniorów, warsztaty z tworzenia lalek teatralnych dla dzieci, wydarzenia masowe, pokazy filmowe dla dzieci, młodzieży i seniorów (różnorodny dobór filmów/różne prelekcje lub dyskusje po seansie), Przegląd Piosenki Aktorskiej we Wrocławiu, Festiwal Teatralny Dialog, międzypokoleniowe projekty artystyczne (we Wrocławiu projekt protoCIAŁO). Podkreślano również, że dla dzieci i ludzi starszych są to zwykle wydarzenia o profilu edukacyjnym lub rozrywkowym (warsztaty, gry, zabawy, filmy). Z kolei dla ludzi młodych i w średnim wieku są to wydarzenia raczej o charakterze intelektualnym (panele dyskusyjne, debaty, konferencje, filmy dokumentalne, performance).

11. Odpowiedz na pytanie: czy dostrzegasz zmiany w odbiorze kultury pomiędzy różnymi pokoleniami? Jeśli tak, jakie są to zmiany?

\begin{tabular}{|l|c|}
\hline \multicolumn{1}{|c|}{ Czy dostrzegasz zmiany w odbiorze kultury pomiędzy różnymi pokoleniami? } & $\mathrm{N}$ \\
\hline tak & 18 \\
\hline nie & 3 \\
\hline
\end{tabular}

Źródło: opracowanie własne.

Kolejne pytanie już bezpośrednio nawiązywało do różnic między konkretnymi pokoleniami, które są widoczne praktycznie dla wszystkich ankietowanych. Respondenci definiują starsze pokolenia jako te, dla których kultura jest raczej sztuką wysoką, mającą przynosić doznania estetyczne, a młodsze pokolenie jako te, dla których kultura jest sposobem na spędzanie wolnego czasu. Ponadto uważają, iż starsze pokolenia raczej preferują kulturę w klasycznym ujęciu: operę, muzykę klasyczną, teatr klasyczny, prasę papierową, książki, bibliotekę, radio, Twitter, telewizję - dostarczającą rozrywkę, są także zdecydowanie bardziej wytrwałe w realizacji działań długoterminowych i bardziej sumienne. Natomiast młodsi oczekują, że wydarzenie wywoła w nich silne emocje, zszokuje ich. Mają większą tolerancję na nowatorskie rozwiązania, sięgają po sztukę współczesną, różne gatunki muzyczne, teatr współczesny, popkulturę, Internet, przeglądy kinowe, e-booki, platformy typu Netflix i Spotify, 
audiobooki i do aplikacji mobilnych. Ludzie młodzi są też bardziej wybredni, a czasem wręcz roszczeniowi, preferują inną estetykę — szybciej, gęściej i z nawiązaniami popowymi, ponieważ są to kody, które łatwiej zrozumieją. Zaś starsi ludzie decydują się na wolniejsze dzieła z mniejszym ładunkiem estetycznym.

Zwrócono także uwagę na to, że to właśnie efekt globalizacji, jakim jest dostęp do zagranicznych produkcji, różni konkretne pokolenia - młodzi korzystają z kultury, są jej ciekawsi, ciągle jest ona w stanie ich bawić, aczkolwiek przez kierowanie oferty w głównej mierze do młodych zawęża się potencjał, który można ciągle zdyskontować na starszej publiczności.

Kolejną różnicą może być poczucie odświętności. Ludzie młodsi nie potrzebują i nie czują obowiązku formalnego ubioru, żeby wejść do teatru, a osoby starsze wręcz przeciwnie. Podkreślano także różnice światopoglądowe i technologiczne.

Podział na aktywności kulturalne dla ludzi młodszych i starszych jest czymś naturalnym, a wiek odbiorcy wpływa często na zakres zainteresowań tematyką kulturalną. Ludzie młodsi zawsze będą odbiorcami innej kultury niż starsi. Każdy w kulturze szuka czegoś dla siebie, adekwatnego do jego aktualnego stanu (w tym wieku, statusu, emocji, doświadczeń). Zmiany, jakie można dostrzec, a raczej różnice, są czymś normalnym. Problem może pojawić się wtedy, gdy kultura nie wychodzi naprzeciw potrzebom różnych grup wiekowych. Wówczas człowiek w kulturze, szukając siebie, siebie nie znajduje, przez co może czuć się niezrozumiany, pominięty i zlekceważony. Takie negatywne emocje rodzą konflikty międzypokoleniowe, wynikające z dysproporcji i braku adekwatności.

W dodatku w dzisiejszych czasach dominującą cechą młodego pokolenia jest narcyzm, co może mieć swój udział w odbiorze kultury. Widzą oni wtedy często jedyną słuszność swoich racji i poglądów. Starsze pokolenie natomiast, nieprzygotowane na tempo i rodzaj zmian, broni się konserwatyzmem i staje się mało wspierające, a raczej krytykujące. Obie postawy są sztywne, jednak ich źródło jest inne, co może okazać się kluczem do zrozumienia zachodzących zmian.

12. Odpowiedz na pytanie: czy uważasz, że zmiana pokoleniowa może mieć wpływ na kulturę w Polsce? Odpowiedź uzasadnij.

\begin{tabular}{|l|r|}
\hline Czy uważasz, że zmiana pokoleniowa może mieć wpływ na kulturę w Polsce? & N \\
\hline tak & 18 \\
\hline nie mam zdania & 3 \\
\hline
\end{tabular}

Źródło: opracowanie własne.

Każda zmiana pokoleniowa oddziałuje na kulturę. Uczestnicy zawsze są częścią procesu tworzenia. Są pewnego rodzaju soczewką, przez którą wydarzenia są przepuszczane i które nadają im pewien kształt. Każde pokolenie może mieć nieco inne oczekiwania związane z realiami świata, w którym żyje. Technologia to główny aspekt, który będzie mieć wpływ na te zmiany, będzie ona jeszcze bardziej oswojona, ponieważ jest 
czymś naturalnym dla osób urodzonych w dobie nowych technologii. Może mieć też wpływ na popularność danych kierunków preferowanych przez młodszych odbiorców kultury, nie zaś na ich liczbę. Kultura jest skierowana zarówno do widza przeciętnego, jak i bardziej wymagającego i ta proporcja powinna być raczej podobna w przyszłości.

Ankietowani mają również nadzieję, iż różnorodna oferta działań kierowanych do dzieci sprawi, iż w przyszłości kulturę będzie konsumować się częściej i chętniej, przestanie się ją traktować jako coś nabożnego, a zacznie postrzegać jak coś codziennego, normalnego, potrzebnego.

Jeden $\mathrm{z}$ ankietowanych podkreśla, że polska elita społeczna została przez ostatnie dwieście trudnych lat skutecznie wymordowana (zabory, wojna, komuna). Jesteśmy przez to narodem "chamów”. Potrzebujemy dużo czasu (pokoleń), życia w wolności, żeby elity społeczne się odrodziły i skutecznie przywróciły życie kulturę do codzienności.

\section{Podsumowanie}

Kultura zawsze jest aktualna dla epoki i regionu, w którym jest tworzona. Jeśli jest ona związana ze zmianą pokoleniową, będzie mieć wpływ także na wiele aspektów funkcjonowania społeczeństwa. Aktualne zmiany następują szybciej niż kiedyś, co powoduje dużą dysproporcję między pokoleniami. To rodzi brak zrozumienia i nieporozumienia, a takie emocje mają swój udział i efekt w działaniach kulturalnych. Kultura zawsze jest i będzie „społecznie zaangażowana”, tyle że adekwatnie do danej sytuacji w kraju. Komentarz, jaki pozostawia, jest „zbiorowym śladem” w historii.

\section{Intergenerational communication in Polish culture}

Summary

The object of this paper is to verify the structure of communication in cultural discourse in Poland. It is analyzed if this discourse sees differences between the next generations and if it personalizes communication for them. Pilot research (CAWI) was done in May 2017. Twenty-one responders answered 7 opened and 5 closed questions in an online survey. All of the responders were working in cultural institutions. The categorization of the answers gave an image of the social groups that have some specific and unique characteristics and values. The quantitative analysis of the answers verified the hypotheses: cultural discourse creates communication according to the audience - which is generation specific. Cultural institutions see this generation problem in Poland and they attribute this change to the activities that have been created for people. This research is only an opening to further investigations on this topic. 